\title{
TERT Deficiency
}

National Cancer Institute

\section{Source}

National Cancer Institute. TERT Deficiency. NCI Thesaurus. Code C126291.

A condition of decreased or absent presence of telomerase reverse transcriptase.

Deficiency of this protein is associated with autosomal dominant dyskeratosis congenital

2, autosomal recessive dyskeratosis congenita 4, telomere-related pulmonary fibrosis, and bone marrow failure 1. 